houses are constructed in large measure by the residents themselves and which are generally, but not exclusively, formed illegally. ${ }^{1}$ The growth of settlements in Lima has occurred in the

Squatter Settlements and Policy Innovation in Peru

David Collier

The reformist military government which has ruled Peru since 1968 has introduced important innovations in policy toward squatter settlements. Taken together, these innovations constitute a coherent policy which appears to be one of the more successful aspects of the government's effort to transform Peruvian society. At the same time, however, the program in the settlements is a curious blend of policies from earlier periods-drawing not only on policies of a previous reform government, but also on policies proposed and carried out by the Peruvian Right.

This chapter analyzes the steps through which the current programs in squatter settlements have evolved, focusing primarily on policy toward the settlements of Lima. It begins with a description of the growth of settlements in Lima and a characterization of government policy in earlier periods. Two phases of the evolution of policy under the present government are then examined: the definition of priorities up to the Pamplona invasion of May 1971 and the consolidation of the policy since that invasion. A concluding section places current policy in perspective by contrasting it with policy in other countries and under earlier governments in Peru.

\section{SQUatTER SeTtlements in Lima}

The expression squatter settlement is used here to refer to residential communities formed by low-income families in which the

This is a revised version of a paper presented to the Seminar on Continuity and Change in Contemporary. Peru of the Center for Inter-American Relations on April 13, 1973. I would like to acknowledge the valuable suggestions of Abraham F. Lowenthal, Alfred C. Stepan, Patricia H. Marks, Ruth B. Collier, Henry A. Dietz, Marcia Koth de Paredes, and members of the Peru Seminar. Alfred Stepan assisted with several important points of fact and interpretation, which are acknowledged in the notes, and also called my attention to useful documentary sources. context of a massive increase in the city's population. As can be seen in Table 4.1, the population of the Lima metropolitan area increased by a factor of more than 20 from 1908 to 1972, growing by nearly $24^{\circ}$ percent in the thirty-two-year period from 1908 to 1940 and by nearly $54^{\circ}$ percent in the thirty-two years from $194^{\circ}$ to 1972 . The growth of the settlement population has occurred primarily during the second of these two periods. Starting from a negligible level in 1940 , it rose to over three hundred thousand by 1961 , representing 20 percent of the metropolitan population, and over nine hundred thousand by 1972, representing 27 percent of the metropolitan population. There has been substantial additional growth since 1972 .

This growth of the settlement population must be seen as stemming both from the problems and from the opportunities posed by rapid urban growth. The problems posed by urban growth for city dwellers and development planners are well known. In the context of rapid growth, major efforts are required merely to maintain previous levels of welfare in such areas as housing, employment, and health facilities. The widely held goal of increasing welfare is often unobtainable.

The growth of squatter settlements in Lima has helped to ease one of the major problems associated with rapid urban growththe shortage of low-income housing. This shortage was first noted at least as early as 1922 with the publication of Alberto Alexander's Estudio sobre la Crisis de la Habitación en Lima, ${ }^{2}$ and the problem has received wide attention since that time. Settlements help ease the shortage by providing rent-free housing for well over a hundred thousand low-income families ${ }^{3}$ and offering opportunities for improvement of housing by the residents and for commu-

I The requirement of illegality has been loosened in this definition to permit the inclusion of government-sponsored settlements which are similar to other settlements in most regards except for the fact of government sponsorship. The definition thus follows roughly the current use of the term pueblo joven The definiti

2 Lima: Imprenta Torres Aguirre, 1922.

3 This estimate is based on the population figure in Table 4.1 and on two assumptions: that there are roughly five individuals per family, and that a sig. nificant proportion, but substantially less than a majority, of families in settlements are subletting. If settlement growth since 1972 were included in this calculation, this estimate would be even higher. 
TABLE 4.1

Selected Data on the Growth of Lima

\begin{tabular}{|c|c|c|c|c|c|c|}
\hline & $\begin{array}{c}\text { Lima } \\
\text { Population } \\
\text { (Metropolitan) } \\
\text { (1) }\end{array}$ & $\begin{array}{c}\text { Lima } \\
\text { Settlement } \\
\text { Population } \\
\text { (Metropolitan) } \\
\text { (2) }\end{array}$ & $\begin{array}{l}\text { Settlement } \\
\text { Population/ } \\
\text { Metropolitan } \\
\text { Population } \\
\text { (3) }\end{array}$ & $\begin{array}{c}\text { Lima } \\
\text { Population/ } \\
\text { National } \\
\text { Population } \\
\text { (4) }\end{array}$ & $\begin{array}{c}\text { Lima } \\
\text { Presidential } \\
\text { Vote } \\
\text { (Department) } \\
\text { (5) }\end{array}$ & $\begin{array}{l}\text { Lima Vote/ } \\
\text { National } \\
\text { Vote } \\
(6)\end{array}$ \\
\hline 1908 & 154,615 & - & - & $3.9 \%$ & - & - \\
\hline 1919 & 199,200 & - & - & $4.2 \%$ & 19,810 & $9.7 \%$ \\
\hline 1931 & 341,720 & - & - & $6.2 \%$ & 34,747 & $28.2 \%$ \\
\hline 1940 & 520,528 & $\begin{array}{c}\text { Probably } \\
<5,000\end{array}$ & $<1.0 \%$ & $8.4 \%$ & - & - \\
\hline 1961 & $1,578,298$ & 318,262 & $20.2 \%$ & $17.0 \%$ & $757,403(1963)$ & $41.7 \%(1963)$ \\
\hline 1972 & $3,317,000$ & 903,394 & $27.2 \%$ & $24.2 \%$ & - & - \\
\hline
\end{tabular}

Sources:

The data in columns $1,4,5$, and 6 were adapted from tables kindly supplied by Carl Herbold. The sources for columns 1 and 4 are Dirección de Salubridad Pública, Censo de la Provincia de Lima de 1908 (Lima, 1915); Dirección de Estadística, Resumenes del Censo de las Provincias de Lima y Callao de 1920 (Lima, 1927); Junta Departmental Pro-desocupados, Censo de las Provincias de Lima y Callao en 1931 (Lima, 1931), p. 46; Dirección Nacional de Estadística, Censo Nacional de Población y Ocupación de 1940, vol. 5 (Lima, 1944), p. 5; A. Arca Parró, "La ciudad capital de la República y el Censo Nacional de 1940," Estadística Peruana, 1, no. 1 (1945), pp. 24-29; and Dirección Nacional de Estadística y Censos, Centros Poblados, 3 (Lima, 1966). The figure for 1972 is a preliminary estimate of the results of the 1972 census released by the Oficina Nacional de Estadística y Censos as reported in La Prensa, Sept. 23, 1972, p. 1. The national population figure for 1908 is from Arthur S. Banks, Cross-Polity Time-Series Data (Cambridge: M.I.T. Press, 1971). Interpolations were carried out by Carl Herbold in a few cases to provide data for comparable years.

The election data are from Dario de Debates de la Asamblea Nacional, 1, pp. 166-170: Extracto Estadístico del Perú: 1931-19321933, pp. 265-266; Jorge Basadre, Historia de la República del Perú, 14, p. 168; Rudolph Gómez, The Peruvian Administrative System (Boulder: University of Colorado Bureau of Government Research, 1969), p. 27; Richard W. Patch, "The Peruvian Elections of 1963," pp. 498-513 in Robert D. Tomasek, ed., Latin American Politics (Garden City: Doubleday, 1966), p. 509; and Carlos A. Astiz, Pressure Groups and Power Elites in Peruvian Politics (Ithaca, N.Y.: Cornell University Press, 1969), p. 50.

The estimate of the settlement population in 1940 is based on data compiled by the author. The figure for 1961 is from the national census of that year, cited above. The figure for 1972 is based on the estimate published in the Informe Preliminar del Censo, 1970 (Lima: Oficina Nacional de Desarrollo de Pueblos Jóvenes, 1971), with the following modifications; (1) 217,050 was added to the figure as an estimate of the population of the settlements formed in 1971 and 1972; (2) a number of settlements were removed from the calculation because they were originally formed by renting, having been included in official definitions for political reasons; and (3) a few others were added which are not included in official definitions, but which were clearly settlements in their pattern of formation. The figure thus arrived at may be a low estimate, since the main source used is two years out of date. However, it seems likely that a great many of the residents of the settlements formed during these two years came from the older settlements-hence reducing the size of this error. 
nity development projects based on cooperation among neighbors. ${ }^{4}$ By providing a setting in which residents can invest their own labor in building homes and in community developmentand often in raising a few chickens or pigs as well-settlements permit the development of what may be called an urban subsistence economy, ${ }^{5}$ which not only eases the housing shortage, but also makes it easier for poor families to manage on low incomes.

The advantages of settlements in Lima are especially pronounced because Lima offers a highly favorable geographical and climatic setting for settlement formation. Because of the mild winters and the virtual absence of rain on the Peruvian coast, the minimal straw houses that first appear when settlements form are far more adequate than they would be in a less favorable climate. The absence of rain also simplifies drainage problems in these communities and eliminates the danger-common in other areas of Latin America-that settlements may be washed down hillsides in heavy rains. Finally, much of Lima is surrounded by unused desert land, which increases the opportunities for the formation of new settlements.

At the same time that the growth of settlements in Lima has served to help meet the problem of rapid urban growth, the appearance of settlements must also be understood as a response to

4 See José Matos Mar, "Migration and Urbanization-The 'Barriadas' of Lima: An Example of Integration into Urban Life," pp. 170-190 in Philip M. Hauser (ed.), Urbanization in Latin America (New York: Columbia University Press, International Documents Service, 1961); Daniel Goldrich, et al., "The Political Integration of Lower-Class Urban Settlements in Chile and Peru," Studies in Comparative International Development 3, no. 1 (1967-68), pp. 1-22; William Mangin, "Latin American Squatter Settlements: A Problem and a Solution," Latin American Research Review 2, no. 3 (1967), pp. 65-98; and Mangin, "Squatter Settlements," Scientific American 1967), pp. 21-29; John F. C. Turner, "Barriers and Channels for Housing Development in Modernizing Countries," Journal of the American Institut of Planners 32, no. 3 (May 1967), pp. 167-181; and Turner, "Uncontrolled Ur ban Settlement: Problems and Policies," International Social Development Re view no. 1 (United Nations, 1968), pp. 107-130; Sandra Powell, "Political Participation in the Barriadas: A Case Study," Comparative Political Studies 2, no. 2 (July 1969), pp. 195-215; Henry A. Dietz, "Urban Squatter Settlements in Peru: A Case History and Analysis," Journal of Inter-American Studies no. 3 (July 1969), pp. 353-37o; and Frank M. Andrews and George W. Phillips, "The Squatters of Lima: Who They Are and What They Want," Journal of Developing Areas 4, no. 2 (Jan. 1970), pp. 211-224.

5 This expression was suggested by Valmar Faria. the political opportunities which arise from urban growth. Because of the growing demographic importance of Lima relative to the rest of the country, any party or program which can successfully reach a major portion of Lima's population thereby reaches a substantial proportion of the nation's population. The growth of the relative importance of Lima is clearly shown in columns four through six in Table 4.1. The population of the Lima metropolitan area as a proportion of the national total rose from 3.9 percent in 1908 to 8.4 percent in $194^{\circ}$ and 24.2 percent in 1972. The growing political importance of Lima is reflected in the rising proportion of the vote in national presidential elections which is concentrated in the Lima area-in this case in the department of Lima. It increased from 9.7 percent in 1919 to 41.7 percent in 1963 . Though national elections are not being held in the present period of military rule, Lima's electoral importance continues to be of great political relevance because major political rivals of the government are parties whose power has been based in electoral strength. In light of the growing importance of the population of Lima, it is hardly surprising that all governments have been intensely concerned with programs which aid the growing population of the city.

It is only recently, however, that there has been full recognition of the degree to which settlement formation has occurred in response to opportunities for gaining political support. ${ }^{6}$ It appears that through tolerating squatter invasions, and in many cases through encouraging the occupation of unused land on the periphery of Lima, both governments and political parties have worked actively to gain support from this increasingly important sector of the Lima population. This political involvement in settlement formation is an important part of the background of present policy and therefore requires some attention in the present analysis.

Government and Party Involvement in Settlement Formation

The first major period of government support for settlement formation occurred under the government of General Manuel Odría

6 See my "Politics of Squatter Settlement Formation in Peru," in David Chaplin (ed.), Peruvian Nationalism: A Corporatist Revolution (New Brunswick, N.J.: Transaction Books, Inc., 1975). 
from 1948 to $1956 .^{7}$ It is fair to say that Odria's involvement in settlements was so extensive that it was an important factor in causing settlement formation to become a large-scale movement in Lima.

The involvement of Odría in settlement formation must be understood against the background of the unsuccessful attempt to bring Apra into the Peruvian political system in the mid194.os. Apra, a middle-class, reformist party with a strong base in the labor movement, had been outlawed during the 193 os and early 1940s. In 1945, Apra was allowed to enter the national elections of that year. As part of the National Democratic Front, Apra won the presidency for the non-Apra presidential candidate of the coalition, as well as a majority in Congress. The following three years were a period of vigorous efforts by Apra to build its party and union base, of a disastrous impasse between Apra's congressional majority and the president, and of widespread political violence, much of which appeared to be attributable to Apra. This violence was climaxed by an attempt by one faction of Apra to carry out a military coup in early October 1948. General Manuel Odría had already been building an antiApra coalition for many months, and in the face of Apra's attempted coup, and with the strong support of the Peruvian oligarchy, Odría carried out his own coup, thereby initiating nearly eight years of military rule.

Apra had already been outlawed before the coup, and Odría moved quickly to destroy its power and the union and party groups which it had formed. Large numbers of Apra members were arrested, others went into exile, and unions linked to Apra were destroyed or were taken over by leaders sympathetic to Odría. However, Odría's campaign against Apra was not based solely on repression, but equally on a strong appeal to the lower class in which he tried to offer an alternative to the kind of popular mobilization that Apra was promoting. Odría attempted to establish a more paternalistic relationship between government

7 This brief history of government involvement in settlement formation in Lima is based on extensive interviews with individuals who were involved in the formation of settlements, as well as newspaper accounts and other published sources. For a discussion of these interviews and documentary sources, see my "Politics of Squatter-Settlement Formation." This article includes the tabulations which form the basis for the conclusions regarding the relative importance of the different periods and the different types of formation. and the lower class by placing heavy emphasis on charity and gifts. It would appear that a major purpose in doing this was to provide an alternative to the political arrangement which Apra had been trying to promote in which benefits from the government came in response to mobilization and articulation of political interests.

One of the most important aspects of Odría's effort to reestablish paternalistic politics was his extensive promotion of the formation of squatter settlements. At times through covert suggesttions that the government would not interfere if a particular piece of land were occupied, at times through public authorizations, Odría actively promoted the formation of new settlements. He also made extensive use of settlements as a source of political support. Some settlements were named after people or dates associated with his government, and settlement residents were periodically marched to the main plaza in front of the presidential palace for demonstrations in support of the government. The largest and most important settlement formed during this period was named "the Twenty-Seventh of October," after the date of Odría's coup. To move to this settlement, one had to apply to an association run by close associates of Odria's. Particularly toward the end of his term of office, when he was considering running for president again in $195^{6}$, those who moved to the settlement were required to become members of his party. Evidence of association with Apra made it difficult to get a lot. Through these organizational ties, and through frequent personal visits, Odría and his wife developed a particularly close identification with the Twenty-Seventh of October.

It may thus be argued that in addition to serving as an important kind of aid for the urban poor and as a source of political support, Odría's activities in the settlements had another important purpose as well. This was the purpose of undermining a particular type of political relationship, one in which forceful political demand making was carried out by groups organized to a considerable degree along class lines in parties and unions. This feature of settlement policy would appear again under the military government which came to power in 1968 .

Since the period of Odría, the government role in settlement formation has varied greatly. There was a less active role in the authorization of new settlements during Prado's second presidency from $195^{6}$ to 1962 , a period of rigid prohibition of inva- 


\section{6-David Collier}

sions in the early sixties, and a 1961 squatter settlement law that set up a procedure through which the government could legally be involved in the formation of new settlements. However, because numerous problems arose in applying the law, the government housing agency empowered to carry out the law had returned by the mid-ig6os to a relatively informal pattern of authorization that differed little from what had occurred before the law.

The national government has by no means been the only source of support for settlement formation. Toward the end of Odría's term of office, a group of conservative leaders who wanted to be sure that Odría did not stay on as president after 1956 began to make preparations for the 1956 presidential elections. Most Peruvians who have had long experience with settlements believe that one of the leaders of this group, Pedro Beltrán, was involved in sponsoring one of the largest squatter invasions ever to take place in Peru, that of the Ciudad de Dios (City of God) settlement, on Christmas Eve 1954. It would appear that these leaders believed that if they were to compete politically with Odría, they needed to have their settlement as well. Beltrán was the owner of the newspaper La Prensa, and he became widely known in the 1950 os for his energetic campaign for innovations in housing policy. His newspaper made frequent editorial reference to the Giudad de Dios invasion as evidence of the seriousness of the housing shortage, and this settlement was used as a site for trying out certain of the housing innovations which Beltrán was promoting. ${ }^{8}$

Support for settlement that did not involve the national government has taken other forms as well. The second Prado government, from 1956 to 1962 , was the hey-day of the traficante, who made a living working as an invasion leader and an adviser to settlements on legal and other problems. Though these leaders made use of party and government linkages, they were usually quite ready to shift their political loyalties when the situation required. In the Belaúnde period, from 1963 to 1968 , there were at least four cases of sponsorship of settlements by opposition parties, principally Apra, which controlled municipal governments. Various types of formation occurred as well, including a spectacular case in 1968 in which Apra arranged an

8 See, for instance, the editorial page of La Prensa, Dec. 29, 1954; Jan. 4 and 7 , 1955; Jan. 1, Mar. 29, and Oct. 10, 1956; and Dec. 7 and 26, 1957 .
Squatter Settlements and Policy -137

invasion of land which was thought to belong to a prominent political opponent of Apra, Enrique León Velarde. León Velarde was the wealthy mayor of the settlement district formerly known as the Twenty-Seventh of October, which had been a major center of support for Odría. The purpose of the invasion was to force the mayor to call the police and evict the invaders, thereby discrediting him as a friend of the poor. Squatter invasions were clearly part of the political game in Lima.

Housing Policy and Legal Status

BEFORE 1968

Apart from noting the role of the government and parties in supporting settlement formation, it is useful to introduce two other aspects of settlement policy before turning to an examination of policy under the present government: the role of settlements in general housing policy, and policy regarding the legal status of settlements.

\section{Housing Policy}

Though settlements have long contributed to easing the housing shortage in Lima, it was only in the mid-1950s that a recognition of their contribution began to influence discussions of housing policy. The long delay in this recognition is hardly surprising in light of the depth of the prejudice against settlements among the middle and upper classes of Lima. These prejudices are reflected in some of the labels which have been applied to settlements, such as cinturón de miseria (belt of misery), urbanización clandestina (clandestine housing development), aberración social (social aberration), and cancer social (social cancer).$^{9}$

Early attempts to deal with the housing shortage focused on the construction of houses by public or semipublic agencies. Examples of this approach may be found at least as early as a 1918 law which authorized the state to build housing for public employees, and numerous laws have been passed since then which directly authorize the construction of housing projects or estab-

9 These are just some of the various terms used in the Lima press, particularly in the 1950s. See also Pablo Berckholtz Salinas, Barrios Marginales: Aberración Social (Lima: 1963). 
lish semiautonomous agencies concerned with the construction of housing. ${ }^{10}$ The Ministry of Development has played a major role in housing projects, and the three semiautonomous agencies founded before the mid-195os which were most actively involved in housing construction in metropolitan Lima were the Corporación Nacional de la Vivienda, the Junta de Obras Públicas del Callao, and the Fondo Nacional de Salud y Bienestar Social. ${ }^{11}$ These three agencies had built over ten thousand housing units by the late 1950 s, and thousands of other units had been built by other public or semipublic organizations. ${ }^{12}$

Other early measures dealing with the housing crisis included rent control and regulations intended to prevent the construction of substandard housing. ${ }^{13}$ However, it appears that rent control may have inhibited investment in new housing, thereby worsening the shortage. Zoning requirements were so unrealistically strict that they could not be enforced and in fact gave the government less control over new housing developments than it might have had with more realistic standards. The construction of an important type of low-cost housing was banned, in spite of the fact that it was superior to many slum areas in which poor families lived.

One of the individuals who did most to change these approaches to housing problems in Peru was Pedro Beltrán, the conservative leader and newspaper editor referred to earlier. Beltrán's newspaper campaign of the mid-1950s dealing with housing and Prado's Supreme Decree No. 1 (August 10, 1956), which created a Commission for Agrarian Reform and Housing with Beltrán as president, did much to initiate the debate on

10 See Peru, Corporación Nacional de la Vivienda, Experiencias Relativas de La Vivienda de Interés Social en el Perú (Lima, 1958) and Luis Dongo Denegri, Vivienda y Úrbanismo (Arequipa: 1962).

11 Corporación Nacional de la Vivienda, Experiencias Relativas, pp. 9-48. 12 This is the author's calculation based on the report of the number of units in each of a large number of different projects reported in Corporación Nacional de la Vivienda, Experiencias Relativas.

13 See Peru, Comisión para la Reforma Agraria y la Vivienda, Report on Housing in Peru (Mexico City: International Cooperation Administration 1959), pp. 24-25; Luis Dorich T., "Urbanization and Physical Planning in Peru," in Philip M. Hauser, Urbanization in Latin America, pp. 283-285. Walter D. Harris, Hans A. Hossé, et al., Housing in Peru (Washing Pan American Union, 1963), pp. 405-406 and 408; and Dietz, "Squatter Settlements," p. 354. housing in Peru. ${ }^{1+}$ Through his newspaper, through the Report on Housing in Peru, the report of his commission which was published in Spanish and English, and through the National Housing Institute, which he founded in 1960 when he was prime minister, Beltrán brought fundamental changes in housing policy.

Beltrán's program was based on the supposition that it was unrealistic to expect that the state would, by itself, have sufficient resources to solve the housing problem. ${ }^{15}$ The solution was to stimulate self-help housing developments and to increase the role of the private sector in solving the housing shortage. Beltrán devoted particular attention to the potential for self-help which existed in the squatter settlements. ${ }^{16}$ Another widely publicized aspect of Beltrán's self-help approach was the inexpensive housing unit called la casa barata que crece, the inexpensive house that grows. ${ }^{17}$ This was a low-cost nuclear house to which additions could be made by the residents. One of the best-known examples of a project which used this type of dwelling was constructed in the Ciudad de Dios settlement, ${ }^{18}$ whose formation had been aided by Beltrán. The activity of the private sector would be stimulated by the elimination of rent-control laws and a variety of other provisions that would stimulate investment in housing, including the introduction of mutual savings and loan associations, with which Beltrán was closely identified. ${ }^{19}$

Another center of innovative thinking about housing in the late 1950s was the Corporación Nacional de la Vivienda, founded in $194^{6,20}$ which was referred to above. Though this agency had earlier been associated with conventional public housing projects, a number of people in the agency had come to recognize the great potential for community development which existed in the settlements. It was through a combination of the efforts of people in this agency and of leading legislators such as Dr. Arca Parró

${ }_{14}$ The editorials referred to in note 8 are a very small sample of the massive attention given to this topic in La Prensa. Supreme Decree No. 1 is included in the Report on Housing in Peru, app. 1.

15 Report on Housing in Peru, p. 77.

16 Ibid., chap. 5 .

17 A story in La Prensa, Jan. 1, 1956, referred to 1955 as the year of La casa barata que crece.

18 See La Prensa, May 11, 1961.

19 Report on Housing in Peru, chap. 7 .

20 See Luis Dongo Denegri, Vivienda y Urbanismo, pp. 26-56. 
that legislation was drafted which eventually became Peru's most important piece of squatter settlement legislation, Law 13517, passed in $1961 .{ }^{21}$ The provisions of this law are discussed in greater detail below. In the present context, the important point is that though this law placed considerable reliance on the selfhelp potential of the settlements, it did not rely on the private sector in promoting housing development, but rather on the state. The passage of this law represented a major setback for Beltrán's approach. An important factor in the defeat of Beltrán's approach was the support of Apra for Law 13517. With the 1962 elections not far away, Apra was anxious to pass a piece of legislation which committed the governments to a complete solution to the problem of settlements.

The program of government aid for settlements authorized by Law $135^{17}$ got off to a vigorous start at the end of Prado's term of office and under the military government of 1962-63. However, after 1963 , drastic budget cuts which resulted from congressional opposition and lack of support from President Belaúnde made it necessary to curtail the program. ${ }^{22}$ Belaúnde's reluctance to aid the settlements reflected still another basic approach to the problems of settlements. The overriding concern of the Belaúnde administration was developing the rural areas of Peru. ${ }^{23}$ It was felt that the expenditure of resources to improve low-cost housing in urban areas would only attract more migrants to the cities, thus increasing further the pressures of urban growth. The issue was not what form of aid was most appropriate for the settlements. Rather, it was whether it was appropriate to aid them at all.

Another reason for the lack of interest in settlements may have been Belaúnde's background as an architect and city planner. Though he brought progressive ideas to many areas of policy, he had been identified with the traditional approach to housing

21 Ley de Barriadas (Lima: Distribuidora Bendezu, 1965). For an excellent discussion of this law, see Kenneth A. Manaster "The Problem of Urban Squatters in Developing Countries: Peru," Wisconsin Law Review ^ (1968), pp. 23-61.

22 The budget of the agency administering the law had been cut by 1967 to 11 percent of its 1963 level. See Junta Nacional de la Vivienda, Obra de la Junta Nacional de la Vivienda de julio de 1963 a octubre de 1967 (Lima, n.d.).

${ }^{23}$ See Susan C. Bourque and David Scott Palmer, "Government Policy and Peasant Response in Rural Peru," Chapter 5 of this volume. shortages that emphasized conventional public housing projects, having himself planned the Unidad Vecinal Número Tres, a middle- to low-income project that was constructed in the late 1940s. During Belaúnde's term as president, the most important government investments in housing had little relation to the housing needs of the poor. Instead, the emphasis was on handsomely designed projects for middle- and upper-middle class families, of which the San Felipe project is an outstanding example.

It should be emphasized that there were some innovations in settlement policy during the Belaúnde period. One of these in volved the establishment of a settlement-Chacra Cerro-organized by the national housing office but financed by a private bank, which took direct responsibility for arranging the periodic payments by the residents for their lots. This was reminiscent of the emphasis of the role of the private sector in Beltrán's program and anticipated the active encouragement of the role of banks in settlements under the present government. Generally, however, the Belaúnde period was characterized by a deliberate choice not to take advantage of important opportunities for contributing to the development of settlements.

\section{Legal Status}

Another important aspect of government policy is that relating to the legal status of settlements. A basic feature of settlement development is, of course, their illegality. Not only do they violate the provisions of building codes and zoning regulations; they have, until recently, occupied land to which the residents did not have title.

Because governments have been involved in supporting the formation of settlements and because, for many years, no major effort was made to legalize the settlements, this illegality may be seen as a direct result of public policy. The relationship of the government to this illegality during the Odría period is particularly interesting. In spite of the extensive and public involvement of the Odria government in promoting settlement formation, and in spite of promises to grant land titles to the residents in certain cases, the Odría government in fact rarely granted titles in the settlements. When viewed in terms of Odría's concern with reestablishing a paternalistic relationship between the government and the lower classes, this failure is quite understandable. If 


\section{2-David Collier}

squatters are simply located on public land, their security of tenure appears to depend on the willingness of the state, and particularly the president, to let them stay there. If they receive title, their security of tenure has a formal, legal basis that is indepen dent of the good will of the president. The failure to give land titles thus reinforced the idea that the squatters were dependent on having a special connection with the president of Peru. It would appear that insecurity bred dependency.

Since the end of the Odría government in the mid-195os, however, there has been a growing concern with the need to bring the existing settlements more nearly into conformity with zoning standards, to provide land titles to residents, and to provide a channel for the legal formation of new settlements. Although I have no definitive explanation of this shift in emphasis, it is certainly understandable in light of the changing political context. The relationship of the second Prado government with settlements was very different from that under Odría. Though Prado did occasionally use the settlements as a source of political sup port, this was far less important than it had been under Odria. Hence, Prado was not as concerned with perpetuating the dependency relationship which Odria had encouraged. There was also an attempt to discredit Odría's realtionship with the settlements, and it was therefore useful to adopt a fresh approach to settlement policy. ${ }^{24}$ Finally, Apra was once again legal during this period-in an informal coalition with Prado-and was a major force in pushing for new settlement legislation. Apra did not rely on dependency relationships with the lower classes, but rather on strong organization of the lower classes, and likewise had no desire to perpetuate the legally ambiguous situation of the settlements.

The major piece of legislation through which the legalization of the settlements has been attempted is Law 13517 of 1961 , which, along with its Reglamento, established a procedure for legalizing existing settlements as well as a legal basis for the formation of new settlements. ${ }^{25}$ As a prerequisite for the granting of land titles, the law required extensive remodeling of the settlements, which was to include the rearrangement of lots in a

24 Shortly after Prado came to office, La Prensa carried a number of stories bout Seventh of October which were obviously intended to discredit Odría.

25 Ley de Barriadas.
Squatter Settlements and Policy-143

more orderly pattern and the installation of city services. Full title would not be granted until this remodeling had been completed.

We have already referred to some of the problems that arose in applying this law. The work of the agency concerned with carrying it out was also hindered by the extensive remodeling that was required by the law before titles could be granted. Because of its limited resources, the agency concentrated its efforts on a few settlements which could be remodeled at relatively low cost, thereby narrowing greatly the scope of its legalization efforts.

Toward the end of the Belaunde period, however, new pressures appeared which brought a change in policy regarding legalization. In anticipation of the 1969 elections, contending political parties vied to see which could offer the most attractive program to the settlements, and legalization was clearly a matter of high priority. León Velarde, the mayor of the settlement district which had been known as the Twenty-Seventh of October under Odría, successfully pushed for the passage of a law which eliminated remodeling as a requirement for granting titles in his district. ${ }^{26}$ In mid-1968, in the face of a threatened march on the central plaza by settlement residents to be led by León Velarde, further decrees were passed which extended this change to all settlements. ${ }^{27}$ Hence there was a brief upsurge in the granting of titles at the end of the Belaúnde period, since it could proceed without the expensive remodeling which had previously been required.

\section{The Evolution of Policy from October,} 1968, to the Pamplona Invasion

The military coup of October 3,1968 , brought to power a new government, which quickly turned its attention to squatter settlements. The most important early expression of the govern. ment's approach to settlements came two months after the coup In early December of 1968, the Organismo Nacional de Desar-

${ }_{26}^{6}$ This law-number ${ }_{16} 68_{4}$-is included in Héctor E. Uchuya Reyes, Nor mas Legales de Pueblos Jóvenes (Lima: Ediciones Heur, 1971), pp. 71-77.

27 See Supreme Decree o66-69-FO of July 19, 1968 (La Crónica, July 20, 1968, p. 3) and Supreme Decree o14-68-JC of Aug. 2, 1968 (El Peruano, Aug. $5,1968$, p. 7$)$. 


\section{4-David Collier}

rollo de Pueblos Jóvenes, the National Organization for the Development of Young Towns, later known as ONDEPJOV, was formed. ${ }^{28}$ The importance given to ONDEPJOV was reflected in the fact that it was directly responsible to the president and the prime minister. The most visible innovation that accompanied the founding of ONDEPJOV was the introduction of a new name for settlements-young towns. This innovation followed a precedent already established in Peru of introducing a new name for settlements as a way of signaling a shift in policy. The most widely used term for settlements up through 1968 had been the somewhat derogatory expression barriada, though many different names for settlements had been employed. ${ }^{29}$ An ONDEPJOV publication later suggested that the new term was intended to reflect the recent formation of the settlements, the youth of the settlement population, and the residents' desire for community improvement. ${ }^{30}$ Judging from the wide acceptance of this new name in Lima, it would appear that the government's approach to settlements, as symbolized by the name, has been well received. Earlier name changes did not become part of the Peruvian vocabulary to the same degree.

\section{The Role of Self-Help}

The supreme decree which established ONDEPJOV discussed in detail the positive features of settlements, emphasizing the way in which settlement residents confront their problems of substandard living conditions through self-help. It suggested that the settlement residents had accomplished a great deal with little support from the state, and that if this local initiative were en-

${ }^{28}$ Supreme Decree No. 105-68-FO. This is included in Documento Numero 3, ONDEPJOV (Lima, 1969). The name was changed a few months after the decree from Organismo to Oficina.

${ }^{29}$ Settlements have had many names in Lima over the last twenty years. The most frequently used has been barriada, originally meaning roughly "little neighborhood." Other terms have included barriada popular, urbanización clandestina (clandestine housing development), barriada clandestina, barrio flotante (floating neighborhood), barrio marginado (marginalized neighborhood), pueblo en formación (town in formation), and now young town. A change in name has been used at least twice in the past to reflect a change in policy-with the introduction of the term town in formation by Apra in the mid-195os, and the term barrio marginal (marginal neighborhood) with the passing of the Law 13517 in $1960-61$. However, the term barriada continued to be the most widely used, in spite of these earlier innovations.

30 Boletin Número 1 , ONDEPJOV (Lima, 1969), p. 5.
Squatter Settlements and Policy-145

couraged and directed, even better results could be achieved. ${ }^{31}$ The most important aspect of this encouragement has been ONDEPJOV's vigorous effort to build and strengthen community organization in the settlements through training local leaders and building local organizations based on a series of hierarchical layers that go down to the block level. ${ }^{32}$

The announcement of the members of the executive committee of ONDEPJOV a week after its formation provided further evidence regarding its orientation. ${ }^{33}$ One of the most prominent members was the auxiliary bishop of Lima, Monseñor Luis Bambarén, who had the title "Bishop of the Squatter Settlements." Bambarén was strongly identified with the self-help approach. Another member was Diego Robles, an architect with long experience in settlements and author of an article about opportunities for self-help in settlements. ${ }^{34}$ The executive committee also included three representatives from the settlements, all of whom were leaders in community organizations involved in self-help projects.

Another important figure in early settlement policy, Carlos Delgado, was not a member of the executive committee. Previously a prominent member of Apra, Delgado quickly emerged as an important adviser to the president at the beginning of the period of military rule. Delgado, like Robles, was the author of an article dealing with self-help development in settlements ${ }^{35}$ and had worked in the period before the coup in a government planning office, PLANDEMET, with several people who were later involved in ONDEPJOV, including Robles. There is a striking

31 Decreto Supremo no. 105-68-FO, in ONDEPJOV Documento Número 3 , p. 4 .

"T2 This organizational arrangement is discussed in detail in Henry A. Dietz, "The Office and the Poblador: Perceptions and Manipulations of Housing Authorities by the Lima Urban Poor" (paper presented at the annual meeting of the American Society for Public Administration, 1973), p. I5

${ }^{33}$ See La Crónica, Dec. 20, 1968.

34 Diego Robles, "El Proceso de Urbanización y los Sectores Populares," in Cuadernos DESCO (Feb. 1969), pp. 49-63. This article was written before the military government came to power.

35 See Carlos Delgado, Tres Planteamientos en Torno a Problemas de Urbanización Acelerada en Areas Metropolitanas: El Caso de Lima (Lima: Cuadernos Plandemet, Serie Anaranjada, Asuntos, Sociales, no. 1, 1968). This has also been published in English as "Three Proposals Regarding Accelerated Urbanization Problems in Metropolitan Areas: The Lima Case" Accelerated in John Miller and RaIph A. Gakenheimer (eds.), Latin American Urban Policies and the Social Sciences (Beverly Hills, Calif.: Sage Publications, 1971). 
similarity between the policy recommendations at the end of Delgado's article and the policies which the government has adopted.

Two private community-development organizations also had an important influence. Shortly before the coup, Monseñor Bambarén had established a private Oficina de Pueblos Jóvenes to promote self-help projects in settlements. The new name for settlements was originally proposed by a member of this organization, and the emphasis developed by members of this group on active community organization and self-help played an important part in later policy. Acción Communitaria del Perú has also played an important role. Acción was founded by Acción International of New York, a community-development organization which has initiated private community-development programs in several Latin American countries. One of the purposes of these programs is to introduce innovative approaches to community development in the hope that they will be imitated by government policy makers. ${ }^{36}$ The Peruvian program is now autonomous, supported by the Peruvian private sector. During the first year of the new government, Acción initiated several pilot projects involving community self-help in settlements which became models for the projects later undertaken by the government. The most important of these involved a savings program established in coordination with a private bank through which settlement communities could accumulate capital for the installation of services, particularly electricity. Members of the ONDEPJOV executive committee followed Acción's efforts with considerable interest, making several visits to its main project in the settlement Pamplona Alta. It should also be noted that these two community-development organizations supplied between them all three of the settlement representatives on the ONDEPJOV executive committee.

Though civilians held important positions in ONDEPJOV, military officers played a very dominant role. As of $197^{\circ}$, all of the directors of the four zones of ONDEPJOV within Lima were military officers, as well as twenty of the twenty-one directors of the local ONDEPJOV offices in the provinces. ${ }^{37}$

${ }^{36}$ See Encyclopedia of Associations, $7^{\text {th }}$ ed. (Detroit: Gale Research Company, 1972), p. 817 .

37 See ONDEPJOV, Informe Preliminar del Censo, 1970 (Lima, 1971) pp. $5^{-6}$ and 37 .

\section{The Role of the Private Sector}

The association with Acción was just one aspect of the attempt by ONDEPJOV to increase the role of the private sector in the settlements. There was particular interest in coordinating the activities of the private sector with the self-help efforts of the settlement residents. ${ }^{38}$ One of the most important aspects of this effort has involved encouraging the arrangement initially tried out by Acción in which savings plans are developed with private banks through which money is accumulated for community projects. An early publication of ONDEPJOV included a large table which suggested the ways in which seventeen different types of projects in settlements could be carried out by coordinating the efforts of different combinations of twenty private and public groups. ${ }^{39}$ A massive 392 -page catalogue of public and private institutions which provide services to settlements in Lima, Trujillo, Chimbote, and Arequipa was later prepared for ONDEPJOV by the U.S. Agency for International Development. ${ }^{40}$ This catalogue, like many publications of ONDEPJOV, had on its cover a symbolic triangle representing ONDEPJOV's attempt to coordinate these efforts:

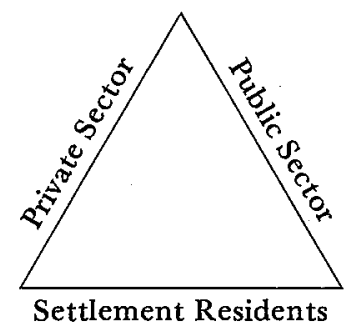

In some of the publications that have used the symbol the following statement appears below the triangle: "Only the combination of the public sector, the private sector, and the settlement residents can achieve the objectives of ... the promotion of the economic development and the social and cultural development of

38 ONDEPJOV, Documento Numero 3, p. 1.

39 ONDEPJOV, Boletin Número $x$, pp. 18-19

40 ONDEPJOV, Catálogo de Instituciones de Servico a la Comunidad: Trujillo, Chimbote, Lima y Arequipa (Lima, 1971). 
the settlements." ${ }^{11}$ If this were a quote from the $195^{\circ}$, one might assume that it was a statement by Pedro Beltrán. The fact that this government has expropriated many of the agricultural holdings of the sector of the rural economy which Beltrán represented and yet has adopted urban housing policies proposed by him illustrates how difficult it is to place the government on a Left-Right continuum.

\section{The Legal Status of the Settlements}

The government is also concerned about the legal status of the settlements. The question of legality has, of course, been an issue for some time. However, it takes on particular interest under the present government because it is an aspect of its overriding concern with law in general, and property law in particular.

The concern with law appears to stem from a belief that am biguous law, and especially ambiguous property law, may be a source of political instability. This belief is in part a product of the military's experience with the rural land invasions and unrest in the Peruvian highlands in the 1960 , which were in considerable measure produced by serious ambiguities in land titles. Many of the land seizures in this period were carried out by peasants frustrated by years of expensive litigation over lands of poorly defined legal status of which they felt they were the rightful owners. ${ }^{42}$

It has been argued that the experience of repressing these peasant movements had a strong impact on the armed forces and convinced them that fundamental changes were required.43 Other events in the 1960 os doubtless contributed to the concern with law and authority as well. These included the scandal surrounding the Act of Talara of August 1968, also involving a question of property rights, and the smuggling scandals of the late Belaúnde period.

41 SINAMOS, Décima Región, Organización Vecinal (Lima, 1972), back cover. This particular example is actually from the period after ONDEPJOV was absorbed in SINAMOS.

42 See John Strasma, "The United States and Agrarian Reform in Peru," pp. 156-205 in Daniel A. Sharp (ed.), U.S. Foreign Policy and Peru (Austin University of Texas Press, 1972), p. 172.

${ }^{43}$ Luigi Einaudi, "U.S. Relations with the Peruvian Military," pp. 15-56 in Sharp, U.S. Foreign Policy and Peru, pp. 22-23.
The government's concern with law was emphasized immediately after the coup. Decree Law No. 1, issued the day after the government came to power, declared that one of the government's objectives was to "restore the principle of authority" and "respect for law" in Peru. ${ }^{4+}$ Since then, this concern has been reflected in a number of policy areas, including the reform of the court system carried out by the Consejo Nacional de Justicia, the more vigorous enforcement of tax law, the campaign for the "moralization" of public administration, and the attack on corruption in the Policía de Investigación Peruana (PIP)..$^{+5}$

The concern with law is also reflected in policy toward settlements. It was clearly expressed in the decree which founded ONDEPJOV, which stated that it was necessary to deal with the problem of property rights in the settlements in the interest of their security and development. ${ }^{* 6}$ Though the program of granting land titles in established settlements would become even more important after the Pamplona invasion in 1971, it was pursued actively from the beginning of the government, first by Junta Nacional de la Vivienda, the housing agency which had been responsible for the application of Law $135^{17}$ during the Belaúnde period, and then by ONDEPJOV. The legalization has been carried out under the terms of Law 13517, as amended by the laws of 1967 and 1968 . Remodeling is therefore not a prerequisite for granting title, and the program can proceed with relative ease.

The government's concern with law is also reflected in the policy toward new squatter invasions. The first two and a half years of military rule saw a lull in invasions in the Lima area. A number of people involved with settlements and squatter invasions were given to understand that the government did not intend to tolerate new invasions. Though there were instances of occupation of new land at the edge of established settlements and one case of a land seizure which resulted from a dispute among members of a housing cooperative, there were no substantial new invasions.

44 El Peruano, Oct. 4, 1968.

45 See Marvin Alinsky, Peruvian Political Perspective (Tempe, Ariz.: Center for Latin American Studies, Arizona State University, 1972), p. 4; and Latin America (weekly newsletter), Sept. 10, 1971, pp. 293-294.

46 ONDEPJOV, Documento Número 3, p. 4. 
The government's determination to prevent invasions was also reflected outside of Lima in October 1969 when a squatter invasion in Talara which received national publicity was met with a firm reaction. This invasion occurred on the first anniversary of the nationalization of the oil complex there, during a visit by President Velasco. The new settlement was named the Ninth of October in honor of the date of the nationalization, and the invaders claimed to have a patriotic desire to commemorate the occasion, but the government moved firmly against them and cleared the site. ${ }^{47}$

\section{Political Support}

Another important aspect of the government's concern with settlements is the desire to use them as a base of political support. Early evidence of this interest may be found in a demonstration of support by settlement residents for the government's policy toward the United States which occurred in the main plaza in front of the presidential palace, just a week after the founding of ONDEPJOV in 1968. This demonstration was organized by Mayor León Velarde, who was involved in the effort to ease the requirements for granting land titles referred to earlier and who was also a close associate of President Velasco. However, León Velarde's demonstration was smaller and less successful than expected, apparently because his political rivals, particularly Apristas, made a major effort to discourage settlement residents from participating. It therefore did not have the desired impact, and it was some time before the government again attempted to arrange a demonstration of this type.

Following this demonstration, the most visible attempt to rally support involved periodic visits to settlements by General Armando Artola, the minister of interior and the member of the cabinet who had the greatest ability to mingle with settlement residents. In light of Odria's role in the settlements, it is noteworthy that Artola's father was a minister in Odría's government. In 1969 Artola made many visits to settlements, often arriving spectacularly in a helicopter and giving away used clothing and panetones (a sweetened bread that is a traditional Peruvian specialty), dancing traditional Peruvian dances, and occasionally

47 La Prensa, Oct. 10, 1969, p. 4. driving the army road graders which were being used to level the streets in settlements. ${ }^{48}$

Two interesting features of these early attempts to develop support in the settlements were the lack of involvement of President Velasco and the lack of coordination between these attempt and the activities of ONDEPJOV. The lack of a presidential role may have been related to the fact-heavily emphasized in the early period of military rule - that this was a government of the military as an institution, and not of the president as an individual. ${ }^{49}$ The higher-level officers in the government were surely aware of the massive personal support which Odría generated in settlements, as well as of the attempt by Pérez-Godoy to undermine the institutional character of the 1962-63 military government and establish an independent base of power. There is even evidence that this attempt by Pérez-Godoy included a preliminary effort to establish a base of power in the settlements. ${ }^{50}$ In light of these past events, it is understandable that the support-getting activity was carried out almost entirely by Artola. He was the odd man out in the cabinet, the subject of much of the criticism of the government which circulated in Lima, and the butt of most of the early jokes about the military regime. Permitting him to play a military populist role in settlements allowed the government to seek popular support in settlements without posing the danger that any member of the government would be able to use this as a major base of personal power. At the same time, however, the fact that Artola's father had been minister in Odria's government might have suggested that giving him free reign in the settlements would be risky. As it worked out, Artola later made a brief attempt to establish an independent base of support in the settlements.

The separation of the support-getting activities from the program of ONDEPJOV is also striking. ONDEPJOV did not seek wide publicity for its activities. An early ONDEPJOV bulletin emphasized the need to avoid excessive publicity and instead to

48 See La Prensa, Feb. 28, 1969; May 2 and 19, 1969; and Expreso, May 26, 1969 .

${ }^{49}$ Einaudi, "U.S. Relations with the Peruvian Military," p. 27

50 According to information collected in the interviews referred to above which were used in reconstructing the history of settlement formation, close associate of Pérez-Godoy's was at one point recruiting people who would carry out invasions. 
focus attention on the task of making ONDEP JOV projects effective as a means of gaining the confidence of the settlement population. ${ }^{51}$ The difference between this approach and that of Artola was dramatized in May of 1969 when Monseñor Bambarén, an important member of the ONDEPJOV executive committee, held a press conference in which he criticized Artola, stating that the problems of settlements could not be solved "by gifts and used clothing" but rather by aiding the residents in building their own houses and helping to provide city services. The headline of an article in Expreso which reported the press conferenceSoluciones, no Panetones (Solutions, Not Panetones)-clearly summarized the divergence in approaches. ${ }^{52}$

This separation between the government's development program and its support-getting activities continued until the founding of SINAMOS in 1971. León Velarde's demonstration might be cited as an example of the coordination of the two aspects of policy, since it occurred just a week after the founding of ONDEPJOV, giving the impression that the demonstration had been planned in part as an expression of gratitude for the new program. However, since one of the settlement representatives on the ONDEPJOV executive committee was a major political rival of León Velarde's, it would appear that the link between these two events was not close. ${ }^{53}$

\section{The Pamplona Invasion}

The government's policy of firmness toward invasions was subjected to a difficult test by the huge squatter invasion which occurred in early May 1971 in Lima, the Pamplona invasion. ${ }^{54}$ This invasion began on an area of public land on April 29, spreading to neighboring areas, both public and private, in a series of invasions that continued until May 12. Tens of thousands of people participated. The government waited several days to initiate at-

51 ONDEPJOV, Documento Número 3, p. 27.

52 Expreso, May 23, 1969

53 The rival, from León Velarde's district of San Martin de Porras, was Alberto Díaz Jiménez. See La Crónica, Dec. 20, 1968.

54 Much of the information regarding the invasion is taken from Manuel Montoya, "El Pamlonazo" (dissertation, Department of Sociology, San Marcos University, Lima, 1972). The newspaper clipping file of Henry A. Dietz was also a valuable aid in reconstructing the history of the invasion. tempts to evict the invaders. A series of clashes then occurred which resulted in injury to many invaders and policemen, and one death. In one incident, police fired into a crowd of invaders; in another, the invaders captured a police commander and threatened to kill him. They agreed to spare his life when he promised to persuade the government to desist in its efforts at eviction. In the compromise which was finally reached, the invaders agreed to move to a government-prepared site to form a large settlement called Villa el Salvador. Only a small nucleus of the original invasion group remained in an area of public land which they had occupied in the invasion.

The invasion occurred during a meeting in Lima of the board of governors of the Inter-American Development Bank, an agency which in the past had given extensive loans to Peru to support low-income housing projects. The incident would have been a serious embarrassment to the government in any case, but the spectacle of a confrontation between poor families and police, and the implication that Peru was not satisfying the housing needs of its low-income population, was particularly embarrassing at that time. Invasions in Lima have commonly been timed to produce a maximum effect, and the timing of this invasion was surely no accident. ${ }^{55}$

Various rumors circulated as to who had planned the invasion. The most plausible version suggests that radical student groups were involved, though some sources hint that support may have come from a faction within the government that wished to dramatize Lima's housing needs and force the government to accelerate its programs in the settlements. It was even suggested that Monseñor Bambarén or Artola had taken part in planning it. Far more important than the question of who organized the invasion, however, was the massive, spontaneous growth of the invasion once it had begun. It demonstrated dramatically the seriousness of the housing deficit in Lima and the vulnerability of the government in the area of housing policy that results from the fact that poor families can meet their housing needs by simply seizing land. It was clear that the slow pace of expansion of

55 A series of invasions occurred around Oct. 3, 1972, the fourth anniversary of the military coup. Under earlier governments, settlements had been formed on occasions such as Odria's birthday, Belaúnde's birthday, Christmas Eve, and Independence Day. 
settlements during the first two and a half years of the Velasco government had left many families unable to get lots in a settlement and eager to join an invasion.

The Pamplona invasion is also of interest because it precipitated a second and final clash between Monseñor Bambarén and General Artola. Artola was identified with the hard line vis-à-vis the invaders, whereas Bambarén, after one of the invaders was killed, went to the invasion site and held a mass. Artola then had Bambarén arrested for disturbing the peace. The church vigorously protested the arrest. ${ }^{56}$ Artola countered by arranging a demonstration by settlement residents which expressed support for his activities in the settlements. ${ }^{57}$ Bambarén was released after thirteen hours, and Artola was forced to resign on May 17.58

Interpretations of Artola's intentions in this situation differ. Some argue that he deliberately delayed the first attempt to evict the invaders, thereby making it more difficult to evict them. It might be speculated that he hoped to increase his importance in the government when he finally succeeded in evicting them, or that he would dramatically choose not to, thereby becoming a hero to the settlement residents. It is difficult to find out which, if either, of these alternatives is true. In either case, Artola was removed from the picture, bringing to an end his spectacular visits to the settlements.

The Pamplona invasion posed a serious challenge to the government's policy of preventing people from obtaining land by simply seizing it, and the government attempted to emphasize that seizure was not a legitimate means of acquiring land. It was announced that "the government will not expropriate these lands in order to. legalize the acts of agitators," 59 perhaps referring to a 1969 law which had expanded the government's ability to ex propriate land for low-income housing projects. It was further declared that "the government is revolutionary, but not disorder ly, and does not believe that the people are ignorant of the proper means to obtain land."60 Further, it was declared that whereas those who had invaded public land could receive lots in Villa el Salvador, those who had occupied private land could not. ${ }^{61}$

56 La Prensa, May 12, 1971. 58 Correo, May 11 and $18,1971$. 60 Ibid.
57 Ibid.

59 Correo, May 15, 1971, p. 14 61 Ibid.

\section{THE Founding of SINAMOS}

Though the Pamplona invasion by itself represented an important crisis for the government, the first half of 1971 was a period of other crises as well, particularly a series of strikes that brought considerable economic and political disruption. These included violent outbreaks in the sugar cooperatives on the north coast and numerous work stoppages in the mines of the central highlands. The miners' strikes had substantially reduced mineral exports, thereby damaging Peru's balance of payments, and were finally ended in late March with the arrest of large numbers of union leaders. ${ }^{62}$

All of these events made it clear that the government needed to increase its ability to deal with the sectors of society capable of mass political action. To help meet this need, the government founded SINAMOS, the Sistema Nacional de Apoyo a la Movilización Social, or National System for the Support of Social Mobilization. Because SINAMOS has taken over most government programs in settlements, this organization merits particularly close attention in the present analysis. It should be emphasized at the outset that in a number of areas the SINAMOS programs have been notably unsuccessful, though the program in settlements would appear to be among the more successful. Apart from the particular degree of success of SINAMOS programs, however, SINAMOS is of particular importance for the present analysis because there are striking parallels and contrasts between the tactics which Odria used to undermine Apra and the approach taken by SINAMOS to weaken political opposition.

Decree Law 18896 of June 22, 1971, which established SINAMOS, declared that this organization was to act as a link between the government and the people, helping to make government bureaucracies more responsive to the public and helping the population to express its desires to the government. ${ }^{63}$ This latter objective would be achieved by actively organizing the Peruvian population as a means of creating links between the population and the government, and through "orienting" the participation of the population. Some of the language of the law resembled that which had been used earlier by the government

62 Latin America, Apr. 23, 1971, pp. 129-130, and June 11, 1971, p. 186. ${ }_{63}$ El Peruano, June 24, 1971, p. 5 . 
with reference to settlements, particularly article $5^{a}$, which said that SINAMOS should help increase the capacity of the population to promote its own development, with the help of the government.

Squatter settlements represent only one sphere of SINAMOS activity. In addition to absorbing ONDEPJOV, SINAMOS is concerned with cooperatives, agrarian reform, and many other areas. However, as the organization of SINAMOS developed, it became clear that settlements occupied a position of special importance. SINAMOS is organized in terms of geographic regions which correspond to groups of departments. For instance, the Fourth Region corresponds to the departments of Lima and Ica, plus the constitutional province of Callao. There is one exception to this territorial pattern, however. The Tenth "Region" of SINAMOS is concerned exclusively with the geographically dispersed settlements of metropolitan Lima, despite the fact that everything else in metropolitan Lima falls within the Fourth Region. ${ }^{64}$ Thus the settlements of Lima were singled out for special attention within the organizational structure of SINAMOS.

The special position of settlements in relation to SINAMOS became even more clear with the promulgation of the Organic Law-a fundamental, enabling law-of SINAMOS, the Decree Law $1935^{2}$ of April 4, 1972. ${ }^{65}$ The introduction to this law described as its goal the establishment of a basically self-directed (autogestora) economy in which the means of production are largely controlled by the workers themselves. ${ }^{66}$ Squatter settlements obviously fit this model of control perfectly. Whereas in many areas, such as the recently expropriated sugar haciendas, SINAMOS must oversee the transfer of control from government supervisors to local cooperatives, the settlements have a wellestablished practice of autogestion. Both in the tradition of local initiative in building houses and community facilities and in the practice of electing community leaders, settlements have long had the organizational characteristics that the government seeks to develop elsewhere. ${ }^{67}$ The self-help orientation of the settle-

64 The regions of SINAMOS are described in the back of the official edition of the Organic Law of SINAMOS (Lima, 1972).

65 Ibid.

$$
66 \text { Ibid., p. } 3 .
$$

67 For a description of local democracy in settlements, see William Mangin, “Squatter Settlements," p. 25. ments is a model for what the government wishes to develop in other sectors of society.

There are various reasons why the government is interested in promoting this kind of organization in Peru, but one of them clearly lies in the types of problems that the government had with strikes in the period before the formation of SINAMOS. These strikes, and perhaps also the Pamplona invasion, had support from opposition parties, including the Left as well as Apra. The government is naturally interested in limiting the power of these parties and in competing with them for support at the local level. Though in some situations SINAMOS has permitted people from these parties to take over local associations-in part because it would be too costly to prevent it - the overall purpose is to create alternative organizations in all sectors of Peruvian society that will fill political space that has been or might be occupied by these parties.

The concern with the role of political opposition in squatter settlements has been particularly intense. Peruvians who were well informed about the thinking of the government in the early stages of the planning of settlement policy report that there was a great concern with the radical potential of the settlements. The attempts of university students to organize the settlements politically and the specter of urban guerrillas in other Latin American countries clearly provided a strong basis for these fears. The concern with radicalization in settlements was apparently expressed frequently by the members of the armed forces who were members of ONDEPJOV in discussions of policy within that organization, and the role of army intelligence in ONDEPJOV and in the settlements themselves has been large. There is considerable surveillance of outsiders who enter the settlements, and individuals known to be affiliated with the Left have on occasion been prevented from visiting them. SINAMOS is actively maintaining and strengthening the elaborate organization of settlements down to the block level which was earlier encouraged by ONDEPJOV, and this organizational structure clearly facilitates political control.

The SINAMOS program in the settlements is closely coordinated with the armed forces in a way that enhances political control. The armed forces have had a direct role in the settlements since the Velasco government came to power. In November 1968, 
a month before the founding of ONDEPJOV, President Velasco announced a substantial program of public works in settlements that would be carried out by the army. ${ }^{68}$ This program has focused particularly on leveling and paving streets, and was responsible for major improvements in an important highway leading to the settlements located to the north of Lima. The Organic Law of SINAMOS specifically reaffirms the role of the armed forces in settlement projects. ${ }^{69}$

The links between the armed forces and SINAMOS go much further than this, however. SINAMOS uses the army radio communications system to conduct much of its business in settlements, which permits instantaneous communication among all of the settlement areas surrounding Lima. Three of the five generals who are commanders of the military regions of Peru, the basic units of territorial division of the command structure of the armed forces, are also the heads of the corresponding regions of SINAMOS. ${ }^{\text {io }}$ In particular, the commander of the Lima military region is also head of the Tenth Region of SINAMOS, the one that is concerned exclusively with Lima settlements. It is striking that this commander is in charge of the region that includes only the settlements, and not the region that includes the department as a whole. Though I was not able to collect complete data on the administration of local offices for the period of SINAMOS administration of the settlements, it appears that there is a continuation of the dominant role of military officers in the directorships of local offices which was noted earlier for the ONDEPJOV period.

Without overstating the importance of the links between the formal structure of the army and the organization of SINAMOS, it is clear that they are related to the government's preoccupation with the potential for radical political activity in the settlements. If an urban guerrilla movement were to develop there, SINAMOS and the army would be in a good position to move quickly against it.

The relationship of SINAMOS with the local leaders in settlements is also a channel of potential control. SINAMOS does not prevent members of political parties from being elected as lead-

68 La Prensa, Nov. 7, 1968.

69 See title five, Disposiciones Complementarias, no. 6.

70 See Actualidad Militar, 11, no. 171 (Jan. 1972), p. 30, and the 1972 official edition of the organic law, pp. 33-34 ers, but will remove them if they act for their party in their leadership role. The only formal requirements for leadership are living in the settlement, being at least eighteen years old and literate, having a known occupation, and having a "good background," that is to say, not having a police record. ${ }^{71}$ Having a known occupation does not mean that a leader is excluded if he is temporarily unemployed. Rather, he must have had a regular job at some point. This provision, along with the requirement of residence in the settlement, is intended to exclude professional political organizers. SINAMOS maintains a central archive of records on all leaders. ${ }^{72}$ Because SINAMOS has made student political organizing in settlements more difficult, has channeled private programs through the leadership structure which it created in settlements, and is keeping close track of these leaders, it has established a substantial degree of control over the political life of the settlements.

\section{Settlement Policy since the Pamplona Invasion}

Since the Pamplona invasion, the government's development programs in settlements have become more extensive and visible, if for no other reason than the massive scale of the program in Villa el Salvador, the government-sponsored settlement formed to accommodate the families who participated in the Pamplona invasion. The government is attempting to develop the settlement through the prompt installation of city services and provision of land titles. The residents may build their own houses or select one of several models of prefabricated houses which are manufactured by the private sector and which are on display in the settlement.

The government's long-run goal is to turn Villa el Salvador into a vast "cooperative city" (ciudad cooperativa). ${ }^{73}$ In 1972 this settlement, which had a population of over one hundred thousand, had more than a thousand local committees which formed the organizational base for the cooperative, and 130 people trained to teach methods for forming cooperatives were working there. The goal is to use the cooperative as a means of dealing not only

71 SINAMOS, Dirigente Vecinal (Lima: 1972), p. 3.

72 Reported by Alfred Stepan, personal communication.

73 See the discussion of plans for this settlement in SINAMOS Informa, 1 , no. 2 (Lima: SINAMOS, Oficina Nacional de Difusión), pp. 29-32. 
with the need for housing and city services, but also with more basic problems of employment. A settlement of this size includes workers from a wide variety of occupations, and the goal is to bring them together in a cooperative which would sell goods and services to the community. To facilitate this, a large area of land close to the community was left unoccupied to provide space for the development of various types of light manufacturing. During the Belaúnde period, land was similarly put aside near a government-sponsored settlement, but this land was later occupied by invasion groups. One important indicator of the commitment of the present government to prevent uncontrolled invasions and to promote the economic self-sufficiency of Villa el Salvador will be whether it succeeds in keeping this reserved land available for its intended use.

President Velasco has developed a close relationship with Villa el Salvador, and he and his wife have made a number of personal visits to the settlement. ${ }^{7+}$ This departs from Velasco's earlier practice of not being personally identified with the settlement programs and corresponds to a decreasing emphasis on the institutional character of the military government. Thus Velasco, like Odria and Beltrán before him, finally has his own settlement and his own base of popular support.

Though the level and scale of activity is lower in other settlements, SINAMOS is actively involved in many other areas as well, promoting the formation of cooperatives for housing and the installation of services. The much stronger framework of community organization which ONDEPJOV and SINAMOS have built in the settlements is an important factor in projects such as the installation of water pipes which are based in part on labor contributed by the residents themselves. Each household is expected to contribute labor to these projects. If a household does not contribute labor and likewise fails to make a financial contribution equivalent to the estimated value of its labor, it will not receive the service. In order to accumulate capital for the acquisition of services, savings schemes have been established with the cooperation of private banks through which funds are accumulated. SINAMOS emphasizes that its role is not one of providing for all of the needs of settlements, but rather of coordinating the efforts of the residents and the private sector in promoting settlement development.

${ }^{74}$ Reported by Alfred Stepan, personal communication.

\section{New Invasions}

The basic pattern followed in dealing with the Pamplona invasion has been applied to other invasions as well. For instance, in the case of a small invasion of an archaeological site outside of Lima in 1972, negotiations between SINAMOS and the invaders resulted in an agreement that the invaders would move to land at the edge of an already established settlement. ${ }^{75}$ On the other at the edge of an already established settlement. ${ }^{.5}$ On the other hand, the government has been unable to enforce this pattern in the case of four invasions which occurred along the Rímac River to the west of the center of Lima in October of 1972, timed to coincide with the fourth anniversary of the military coup. ${ }^{76}$ Though SINAMOS was able to move two of the groups to other sites within the same immediate area, it has been unable to persuade the invaders to move to Villa el Salvador. Even police efforts to contain the invasions produced some violence, ${ }^{77}$ and the government has been unwilling to apply the degree of violence that would be necessary to remove the invaders from the sites. In part in response to the failure to deal successfully with these invasions, the government promulgated Decree Law 20066 of June 26,1973 , which made involvement in invasions punishable by imprisonment of up to two years. This punishment applied not only to those who actually participated in invasions, but also anyone involved in organizing an invasion..$^{8}$

Interviews in SINAMOS offices revealed that there exists a legal means through which families can obtain a lot in a settlement. This via legal involves a program in which lots in government-sponsored settlements are sold to any family which applies for one However, out of fear of stimulating a massive demand for new lots, this program has received little publicity and hence has operated only on a small scale. As of late 1972, a comhas operated only an invasion and then get moved to a government-sponsored settlement. Invasions then continue to be a major means through which families acquire land in settlements. Given the concern with adherence to

75 La Prensa, June 3, 1972.

These invasions in La Prensa and El Comercio almost daily during the first week of October $197^{2}$.

${ }_{77}$ El Comercio, Nov. 13, 1973

Perrian Times, July 6, 1973. I would like to thank Peter Cleaves for calling this law to my attention. 


\section{2-David Collier}

law, it is surprising that the government tolerates, and, because it moves the invaders to new sites, to some extent even provides an incentive for, the occurrence of invasions. The invasions that are occurring are clearly related to a continuing shortage of lowcost housing in Lima. Though opposition parties and land speculators might still be interested in invasions if this shortage did not exist, the elimination of the shortage would unquestionably eliminate one of the causes of these invasions. The program of offering lots to any family which applies for one could alleviate the shortage, but the government is reluctant to develop the program sufficiently to allow this to happen.

The reason for this reluctance presumably lies in the overall development strategy of the government. Through efforts to develop other parts of the Coast, extensive agrarian reform, and programs to develop the Jungle, this government hopes to stem the heavy flow of migration to Lima. ${ }^{79} \mathrm{~A}$ massive program of of fering land in settlements to any family that applied for it would make life in Lima easier for new migrants and would be a stimulus for new migration. It appears that the government is willing to tolerate the continuing occurrence of invasions in Lima as a price it must pay for holding down the rate of migration to the capital. This concern with the consequences of settlement development for urban growth has, of course, already been noted as an important aspect of settlement policy during the Belaúnde period.

Another ambiguity with regard to enforcement of law can be found in policy toward invasions in the provinces. There have been evictions in provincial cities. ${ }^{80}$ However, on the basis of visits to provincial cities, Alfred Stepan reports that the reaction to invasions has been far less harsh outside of Lima. ${ }^{80 a}$ Interviews carried out by Stepan with SINAMOS officials suggest that there is a deliberate strategy of restraining invasions in Lima and letting them occur more freely in provincial cities. This is intended to discourage migration to Lima, and to encourage instead the concentration of migrants in secondary population centers. Concern

79 For a discussion of the government's plans for regional development, see John P. Robin and Frederick C. Terzo, Urbanization in Peru (New York: Ford Foundation, 1973), pp. $25 \mathrm{ff}$.

${ }^{80}$ See La Prensa, Nov. 2, 1969 (Chimbote), June 1, 1971 (Talara and Arequipa), and Aug. 25, 1972 (Chiclayo)

80 Personal communication.
Squatter Settlements and Policy-163

with legality thus once again takes second place to the concern with restraining migration to Lima.

\section{Legalization}

SINAMOS is actively granting land titles in the illegally established older settlements and in $197^{2}$ was processing tens of thousands of applications for titles. Records examined by Alfred Stepan indicate that far more titles were granted from $197^{\circ}$ to 1972 than throughout the ig60s. An interesting aspect of this program of legalization is the requirements imposed for applying for land title in a settlement. Among the documents that SINAMOS requires is a certificate of civil marriage. ${ }^{81}$ This is a particularly significant requirement since a great many couples in settlements are joined only by common-law marriage. Though it is possible to make the application without the certificate, the belief that it will be required has produced a rash of mass marriages in settlewill be required has of commonmigrants and rural Indians as law marriages among cityward migrants and doubtless a source of great satisfaction. This is another way in which the government is extending the rule of law in the settlements.

SINAMOS is also attempting to force settlement residents to occupy the lots of which they claim to be the de facto owners or to give them up. The need to do this arises from the fact that many families have treated squatter invasions as an opportunity for land speculation, initially occupying a lot in a new settlement and building a minimal house on it but not living there. This is done with the intention of moving in later on, or renting or selling the house and lot at some future date. Law 13517 prohibits this, and housing agencies have tried, usually unsuccessfully, to prevent it. In September of 1972 SINAMOS began a major effort to end this practice. ${ }^{83}$ Though obviously confronted by many of the same difficulties that earlier agencies faced in enforcing this aspect of the law, SINAMOS had a greater ability to recover the

81 This was included in a mimeographed list of requirements which was aristh ceravailable at local SINAMOS offces. Other personition the applicant had to be tificates for children were also required. other real estate.

22 For a mass marriages, see La Prensa, Dec. 19, 1972. 83 See La Prensa, Sept. 14, 1972. 
unused lots because of its extensive efforts to organize the settlements. The local settlement organizations collect contributions from the residents for community projects, and to the extent that lots are not occupied, the ability to collect money is correspond ingly reduced. SINAMOS therefore expected full cooperation from the settlement leaders in their campaign, and as of October 1972 they had already recovered a number of lots.

\section{Popular Support}

One of the important consequences of the formation of SINAMOS has been to bring together in one agency the government's programs in settlements and its attempts to mobilize pop ular support. These had previously been divided between ONDEPJOV and Artola. SINAMOS has arranged major demonstrations by settlement residents, such as the demonstration in Chimbote on July 29, 1972, the day after the national independence day, which a SINAMOS bulletin claimed was attended by 120,000 people. ${ }^{84}$ SINAMOS literature on Villa el Salvador likewise focuses on popular support. An article on this settlement in SINAMOS Informa, a news bulletin put out by SINAMOS, in cluded eight pictures of residents of Villa el Salvador engaged in large, enthusiastic demonstrations, waving Peruvian flags and banners which carried slogans supporting the government. ${ }^{85}$

There is a significant divergence between the reality of the political demonstrations arranged by SINAMOS and the officially stated objectives of SINAMOS of supporting "mobilization." The law which founded SINAMOS declares that one of its purposes is to create a dialogue between the people and the government and to stimulate the participation of the people in basic decisions. ${ }^{86}$ The publicity regarding these demonstrations claims that they fulfill these purposes. On various occasions, settlement residents or members of other groups attending the demonstrations have been brought up to the platform to make a statement about their needs. This is referred to in the publicity as "dialogue." 87

84 SINAMOS Informa, 1, no. I (Lima: SINAMOS, Oficina Nacional de Difusión), p. 20.

85 SINAMOS Informa, 1, no. 2, pp. 29-32.

86 Decreto Ley 18896 , article 5 C.

87 See, for instance, SINAMOS Informa, 1, no. 2, p. 32 and Expreso, Oct. 1 , $197^{2}$ (the latter with reference to Velasco's visit to the Jungle).
Similarly, SINAMOS publicity regarding the July 1972 settlement demonstration in Chimbote states that demonstrations of this type are a "consequence of a coherent policy which is intended to encourage the participation of the citizenry in the tasks of development and progress. ${ }^{88}$ The claims of SINAMOS regarding the significance of these demonstrations are also reflected in the main banner that hung below the speaker's platform at the Chimbote demonstration, which said "Tu Presencia es Revolución" ("Your Presence is Revolution") ${ }^{89}$

These demonstrations may reflect considerable support for the government. However, mass involvement in this kind of dialogue, participation, and "revolution" does not really involve the exercise of political power. The emphasis on this type of symbolic participation reflects a basic dilemma of military governments, paren reformist or radical military governments, regarding the even reformist or radical military governments the solution to this dilemma is nicely summarized by Stepan, who suggests that

in regard to participation, the desire of military radicals for control would tend to conflict with free democratic electoral campaigns, but would be congruent with a military populist plebiscitary style of politics. As regards mobilization, military radicals' preference for order and unity would make them ... favorably disposed to mass parades. ${ }^{90}$

At the same time, however, the participation which is being encouraged in settlements by SINAMOS does affect decision making at the local level. Local associations are democratic, and within the limitations imposed on local political activity, settlement residents do exercise choice in decisions about local development programs.

To sum up the impact of the Pamplona invasion on settlemen policy: It is clear that two basic elements of the policy already existed before the invasions-the self-help oriented development program of ONDEPJOV and the support-getting activities of Artola. The impact of the invasion and the other crises of mass

88 SINAMOS Informa, 1, no. 1, p. 14.

89 Ibid. front cover.

(a) Malitary in Politics: Changing Patterns in Brazil (Princeton, N.J.: Princeton University Press, 1971), p. 270. 
participation which occurred at about the same time was to bring these two elements together in SINAMOS in such a way as to strengthen a third element-the capacity for political control. Though the concern with political control was present from the beginning, it was heightened by the crises of early 1971. It therefore appears that these crises of mass participation had an important influence on the way in which settlement policy is being carried out, and perhaps the scale on which it is being carried out. They did not alter the basic methods which are being used to develop the settlements.

Just as the crises of 1971 brought a sharp shift in the organization of the settlement program, so there have also been some changes within the SINAMOS period. Following a series of crises in a number of SINAMOS programs which did not involve settlements and a change in top SINAMOS leadership, there were, by 1974, some signs of a shift to a less populist, more low-profile approach which more nearly resembled the approach of ONDEPJOV. By early 1975, the weakened position of SINAMOS and the uncertainties about the future of the Velasco regime seemed likely to further encourage this tendency.

\section{Analyzing the Policy}

To place current policy in Peru in perspective, I will now point to certain contrasts with policies adopted in other countries, attempt to assess who benefits from the policy, and develop further the comparison with policy under earlier governments in Peru.

\section{Contrasts with Other Countries}

Contrasting present policy with settlement and housing policies in other countries is a useful means of identifying alternative policies which have not been adopted in Peru. For instance, the eradication of existing settlements has occurred under the present military government in Brazil, under Pérez-Jimenez in Venezuela, and in Korea and Africa. ${ }^{91}$ This antisquatter policy

91 Elizabeth and Anthony Leeds, "Brazil in the 1960 's: Favelas and Polity, The Continuity of the Structure of Social Control" (unpublished manuscript); Talton F. Ray, The Politics of the Barrios of Venezuela (Berkeley and Los Angeles: University of California Press, 1969), p. 32; and Joan M. Nelson, has been carried even further in the Central African Republic, where cityward migrants have literally been taken back to the countryside in trucks. ${ }^{92}$ Such alternatives do not appear to have received serious consideration under the present government in Peru. Three reasons may be cited for this. First, Lima's unusual advantages as a setting for settlement formation have caused Lima's settlements to have a far greater potential for progressive development than settlements in many other countries. Hence, there is less reason to eradicate them. Second, it is obvious that the military are aware of the potential in the settlements for selfimprovement and believe that they have played an important and positive role in the growth of Lima. Finally, though opposition parties have been reduced to a relatively weak position in Peru, they would probably be strong enough to encourage and organize forceful resistance if a systematic policy of eradication were adopted. The threatened eradication of established communities has frequently produced violent resistance in Peru. In Brazil, by contrast, the party structure is far weaker and the coexcive potential of the government far greater.

Another important contrast with other countries concerns the extent to which traditional planners' standards have been relaxed in recognition of the contribution of settlements to urban development. Peru appears to be far ahead of most countries in this regard. The writings of Mangin and Turner on Peru were among the first anywhere to call attention to the need to relax traditional standards in order to take advantage of development opportunities in settlements, ${ }^{93}$ and many of Turner's insights came directly out of his work in the housing institute associated with Beltrán in the late $195^{00^{01}}{ }^{01}$ This relaxation of standards has obviously not been initiated by the present government. However, the decision to continue the earlier emphasis is significant.

"New Policies toward Squatter Settlements: Legalization Versus Planners' Standards" (unpublished manuscript). For an example of the apparently common phenomenon of eradication in Africa, see Michael A. Cohen, Urban Policy and Political Conflict in Africa: A Study of the Ivory Coast (Chicago: University of Chicago Press, 1974)

92 Reported by Richard E. Stryker, personal communication.

93 See Mangin, "Latin American Squatter Settlements" and "Squatter Settlements," and Turner, "Barriers and Channels" and "Uncontrolled Urban Settlement." Nelson's "New Policies" and personal communication with her helped to bring the issue of planners' standards into focus.

94 Personal communication from John C. Turner. 


\section{8-David Collier}

Though Peru is innovative in terms of the relaxation of traditional planners standards, policy has been more cautious in two important areas - the extent of development of the via legal for applying for lots in settlements, and the initiation of urban reform. With regard to legal alternatives for the formation of lowincome communities, the policy in Chile under Frei was far more ambitious. $^{95}$ However, the fate of the Chilean project suggests that the hesitancy of the Peruvian government in developing the via legal may be justified. Applications for the program ran far ahead of the government's ability to accommodate new families, and as the elections of 1970 approached, the opposition parties sought to call attention to the failures of the program by supporting the illegal occupation of proposed housing sites by the frustrated applicants. ${ }^{96}$ Hence, the failure of a program intended to offer a legal channel for low-income housing development had the effect of encouraging further illegality. In light of this Chilean experience, the fear of the Peruvian government of raising expectations through a major program of offering lots in settlements seems justified. Such a program would also conflict with the goal of discouraging further migration to Lima.

\section{Urban Reform}

Another policy which has not been adopted is urban reform. Ever since the Cuban urban reform of 1960 , reform governments in Latin America have had a model for the fundamental rearrangement of the ownership of urban property. The Cuban law eliminated renting, put all home construction in the hands of the state, imposed new norms for the inheritance of real estate, and placed future urban expansion under tight government control. ${ }^{97}$

The Cuban law was printed in Lima and circulated widely in the first years of military rule. ${ }^{98}$ Support for urban reform came

95 See Robert North Merrill, "Toward a Structural Housing Policy: An Analysis of Chile's Low Income Housing Program" (Doctoral dissertation, Cornell University, 1971), pp. 11ff., and Peter S. Cleaves, Bureaucratic Politics and Administration in Chile (Berkeley and Los Angeles: University of California Press, 1974), chap. 8.

96 Cleaves, Bureaucratic Politics, chap. 8.

${ }^{97}$ See Maruja Acosta and Jorge E. Hardoy, Reforma Urbana en Cuba Revolucionaria (Caracas: Sintesis Dosmil, 1971), chaps. 5 and 6.

98 Information on this and several of the following points was kindly supplied by Sinesio López.
Squatter Settlements and Policy -169

from the Left-from the magazine Oiga during the first year of military rule when it was to the left of the government; from the most reform-minded members of the government-both civilian and military; and more recently, in 1973, from the Christian Democratic party, the party with the closest ties to the government. ${ }^{99}$ The proposals of Oiga and the Christian Democrats included the expropriation of rented housing. In one version, back rent would have counted as partial payment toward purchase, and the government would have paid the balance. ${ }^{100}$ This would not necessarily have involved all rented housing, and Oiga suggested that small-scale owners who were renting only two or three properties should be exempted. ${ }^{101}$ The reform would also curb land speculation in areas of future urban expansion at the periphery of the city-an important factor in housing coststhrough expropriation of areas of future urban growth and more careful planning of city growth. ${ }^{102}$

President Velasco's Independence Day speech on July 28,1969 , emphatically ruled out the possibility of a general redistribution of urban real estate but made it clear that some control over land speculation was imminent. ${ }^{103} \mathrm{He}$ declared that there would not be urban reform, as some had "self-interestedly" maintained (in part a slap at Oiga), and that the government would not eliminate the right to private property in the form of real estate, but rather would defend it. Instead, the concern of the government was with resolving the problems of squatter settlements and inner-city slums, and with eliminating land speculation. He was particularly forceful on this last point, declaring that

[w] all know that in Peru, immense fortunes have been made through artificially driving up the price of . . land....

This is a situation of appalling injustice which cannot continue in the future. ${ }^{104}$

99 See, for instance, Oiga, Nov. 8, 1968, p. 13; Nov. 30, 1968, p. 11; Mar. 21 1969; Apr. 11, 1969; Sept. 12, 1969, p. 14; and Nov. 16, 1969. See also the Declaración Política, published by the Christian Democrats in Expreso, Apr. 15, 1973 .

100 Oiga, Nov. 9, 1968, p. 13

101 Ibid.

102 This is mentioned in most of the statements on urban reform cited above. 103 Oficina Nacional de Información, "Mensaje a la Nación," July 28, 1969, pp. 13-14. 
This speech naturally raised wide expectations of new measures dealing with settlements and slums and with land speculation. Endless rumors circulated about a new squatter settlemen law. According to one version, the law would attack the problems of inner-city slums by offering new land to the slum residents and then eradicating the slums. ${ }^{105}$ Another version suggested the law involved cooperative ownership of settlements by the residents which would preclude individual ownership of houses. A law based on this latter idea was apparently drafted and circulated in the government, but was not adopted. Rumors of imminent urban reform persisted through 1974-they were particularly widespread in July of that year-but as of mid-1974, settlement policy was still being carried out under the terms of Law 13517, as revised in the late Belaúnde period.

On the other hand, Law $1780_{3}$, dealing with land speculation, came out a little over a month after Velasco's speech. ${ }^{106}$ This law provided the basis for expropriating land for use in low-income housing developments and included fairly strict criteria for determining the price of expropriation and the terms of payment to the owners. The measure was generally well received, with some complaints from private developers about the terms of expropriation. ${ }^{107}$ Since that time, the government has become involved in major low-income housing projects which involved expropriated land.

Why was there such hesitation in adopting urban reform? The parallel with agrarian reform was inviting. In rural areas, Iand invasions had threatened the stability of the system, and land was being redistributed to preempt future invasions. In urban areas, land seizures continued to occur, and it would seem reasonable to preempt them through the redistribution of urban property. However, there were major differences. Redistribution in the capital might conflict with the government's goal of diverting migration from Lima, whereas redistribution in rural areas was obviously consistent with it. Likewise, agrarian reform in the highlands took land from a class of traditional hacienda owners whose political power had long been declining. In urban areas, the private sector played an important role in the government's

105 El Comercio, Sept. 3, 1969.

106 El Comercio, Sept. 5, 1969 .

107 La Prensa, Sept. 19, 1969 . housing plans, and the government perhaps did not wish to demoralize this sector by carrying out extensive expropriations. Other factors may have been influential as well, such as the fact that the government did not want to inhibit private investment in housing with a threatening law, and that some high-ranking military officers own significant amounts of urban real estate.

With regard to the possibility of new, comprehensive legislation for settlements and slums, the proposal for cooperative ownership of settlements was viewed in the cabinet and elsewhere as undermining the principle of private property, and hence was dropped. Because settlements make property owners out of the urban poor, a feature of settlements which has often been viewed as contributing to political stability, the government was apparently reluctant to eliminate this aspect of settlement life. The reasons why the massive relocation of slum residents was not carried out are less clear. If the old slum areas were eradicated, there was no reason why this measure should have stimulated further migration to Lima. It might also have helped to reduce the number and size of the squatter invasions which were occurring in Lima. On the other hand, it would have represented a major assault on private control of urban real estate. It would also have committed the government to a massive task of demolishing old slums and aiding new communities on the periphery of the city. It hence went considerably further than the government was ready to go at that time in aiding the urban poor. However, as the ongoing reforms of 1973 and 1974 touched more and more areas of private property, many observers in Lima felt that new reforms in the area of housing and real estate were likely.

\section{Who Benefits from the Policy?}

Another means of placing settlement policy in perspective is to ask who has benefited from it. We will not attempt to speculate about who benefits from all of the policy changes discussed in this chapter, but rather will identify the beneficiaries in the traditional pattern of settlement formation around Lima, note changes in the perception of who the beneficiaries were, and try to identify the principal beneficiaries under present policy.

To answer the question of who has benefited and who has lost in the traditional pattern of settlement formation around Lima, 
we must consider the broader context of patterns of landholding in Lima. One of the most important aspects of the landholding pattern has been the widespread illegal or legally ambiguous appropriation of land, not only by poor squatters, but by the wealthy as well. Many instances may be found of appropriation of land by the wealthy. Haciendas in the Lima area have been expanded by extending the cultivated land to neighboring publicly owned areas. Homesteading laws, which provide for the acquisition of land for agriculture and mining, have been violated by owners who instead build housing developments. Wealthy individuals who wish to claim a particular piece of public land have been known to sell it to a housing cooperative for low-income families, thereby gaining as allies for their claim an easy-to-mobilize group of poor families who will vigorously resist any attempt to evict them from the site. ${ }^{108}$

The occupation of land by low-income families-with or without encouragement from the government-is thus one aspect of a broad pattern in which many people, both rich and poor, have appropriated land in greater Lima. Policy arenas of this type have been labelled "distributive." 109 They involve a nonzero-sum game in which a highly divisible good is acquired in such a way that there are many immediate beneficiaries and no immediate losers-except, in this instance, for a few cases of conflict among contending illegal claimants.

The evolution away from this distributive pattern may be interpreted as resulting from a change in the political context which caused some groups to conclude that settlement formation was more costly than had previously been realized-that there were, indeed, losers. I suggested above that one aspect of the change in context was the rural instability in the Peruvian highlands in the 1960 s and the link between this instability and ambiguous property law. The military apparently concluded that the ambiguous system of property law had already imposed a high cost by threatening the stability of the system in rural areas, and that it might do so in urban areas as well. The military gov-

108 For a further discussion of the illegal use of land around Lima, see my Squatters and Oligarchs: Public Policy and Modernization in Peru (Baltimore: Johns Hopkins Press, forthcoming, 1976), chap. 2.

109 Theodore J. Lowi, "American Business, Public Policy, Case-Studies, and Political Theory," World Politics 16, no. 4 (July 1964), pp. 677-715, at pp. $692-695$. ernment is therefore attempting to bring order to the system of property law, in urban as well as rural areas.

Though the military fears the radical potential of the settlements, it is important to note that this presumed radical potential has, in fact, not yet produced significant political disruption in Lima. The disruption occurred, instead, in the countryside. Following Hirschman, it may be argued that this is an instance in which a "neglected" problem-landholding arrangements in Lima-received attention in part because its solution is viewed as an aspect of the solution of a "privileged" problem-the landholding arrangements in rural areas. ${ }^{110}$

Other changes in the political context were important as well The idea that settlement formation imposes a high cost by encouraging migration to Lima had already influenced policy in the Belaúnde period. The specter of urban guerrillas in other countries was another factor which affected the military's perceptions of the costs of uncontrolled settlement formation in Lima

These changing patterns of the costs and benefits of settlement formation have caused a shift from a distributive, give-away policy to a policy of attempting to regulate land use. This regulation includes not only the attempted control of settlement formation but also Law 17809 , which laid the basis for regulating land speculation. The shift has resulted from the identification of new in terests-the requirements of a particular national development strategy and the presumed requirements of national securitywhich are now perceived as having been jeopardized by the earlier policy.

There is a striking similarity between this evolution of settlement policy in Peru and Lowi's discussion of the way in which tariff policy in the United States has evolved from a distributive policy to a regulative policy. In the earlier part of this century, most strikingly with the Smoot-Hawley tariff of 1930, United States tariff policy was based on "giving limited protection [indulgence] to all interests strong enough to furnish resistance."111 It involved a situation in which "a billion dollar issue [could] be disaggregated into many millions of nickel-dime items and each [could] be dealt with without regard to the others. . . ."112

Beginning in the 1930s, however,

110 Albert O. Hirschman, Journeys Toward Progress (Garden City, N.Y. Doubleday, 1965), pp. zolff.

111 Ibid., p. 692.

112 Ibid. 
the tariff began to lose its capacity for infinite disaggregation because it slowly underwent redefinition, moving away from its purely domestic significance towards that of an instrument of international politics. In brief, the tariff, especially following World War II and our assumption of peacetime international leadership, became a means of regulating the domestic economy for international purposes. The significant feature here is not the international but the regulatory part of the redefinition. As the process of redefinition took place, a number of significant shifts in power relations took place as well, because it was no longer possible to deal with each dutiable item in isolation. ... Certain elements of distributive politics remain ... [because] there are always efforts to disaggregate policies as the best way to spread the patronage and to avoid conflict. . . But despite the persistence of certain distributive features, the true nature of tariff in the $1960^{\circ}$ 's emerges as a regulatory policy. ${ }^{113}$

Thus with tariff policy in the United States, as with settlement policy in Peru, new, broader interests emerged which could not be served by the earlier distributive pattern.

Turning to the question of who benefits from present settlement policy in Peru, a number of different beneficiaries and losers must be identified. To the extent that it is harder to get a lot in a settlement in Lima, the present arrangement works to the disadvantage of low-income families who would like to move to a settlement. The fact that it is harder to get a lot in Lima may also reduce the overall supply of low-income housing and work to the disadvantage of families who would like to move to the capital but do not because it is more difficult to find housing. These families are the short-term losers in the government's efforts to divert migration from Lima.

On the other hand, the residents of Lima settlements have benefited, particularly through the granting of land titles. The importance of land titles to settlement residents was clearly reflected in a 1967 survey of settlement residents which measured the intensity of dissatisfaction over the absence of twenty-six different services and amenities in settlements. ${ }^{114}$ The lack of land titles was tied for first in terms of intensity of dissatisfaction. It

113 Ibid., pp. 699-701 .

114 Andrews and Phillips, "The Squatters of Lima," p. 218. is clear that the settlement residents are getting something from the government which they very much want. Receiving title increases security of tenure on the lot, stimulates investment in housing, increases the value of the lot, and makes it easier to sell the lot. The active government support for community development projects likewise brings considerable benefits to the settlement residents. The government is unquestionably carrying out an enlightened program in the settlements.

With regard to the broader consequences of the policy, the sector which most obviously loses under present policy is the traditional party system. A major purpose of the policy is to insulate the settlements from the appeals of political parties. The governthe settlements trom the hoped-for slowing of the rate of migration to Lima and the attempt to raise the level of satisfacmigration to Lima and the attempt to raise the level of sability of the politition of settlement residents will increase the stability of the political system. Determining who benefits from the stability of the present political situation obviously requires an elaborate assess-

ment of the benefits and costs of many other gov
which is well beyond the scope of this chapter.

\section{Comparisons with Other Governments}

The policies toward settlements adopted by the present military government appear to be guided by a number of concerns: a desire to stimulate the physical development of the settlements; concern with respect for law; the desire to avoid programs that concern with respect for law; the dima; the desire to reconstruct Peruvian society around partially autonomous units which Peruvian society around autogestion or self-direction; and the attempt to promote a particular type of popular support and controlled mass participation which is unrelated to political demand trolled mass participation which is unrelated to political demand making, except for demands focused at the local level, and which precludes the traditional political parties. Though the government must occasionally choose from among these goals-as in the choice between respect for law and controlling urban growthchoice betwe overall, the basis for a fairly coherent and consistent policy.

At the same time, however, if one examines the precedents for current policy, one finds that it is a curious blend of policies pursued by an earlier progressive government and by the Right. Odria's use of settlements as a base of popular support and as 


\section{6-David Collier}

part of his campaign against Apra anticipated current activities of SINAMOS. Beltrán's emphasis on self-help and the role of the private sector in solving the housing crisis have been revived. Belaúnde's concern with the impact of massive settlement programs on urban growth is also reflected in the present period.

It would, however, be a mistake to argue that the government is merely applying old policies. Even if many aspects of the pol* icy have been tried out under earlier governments, it is an inno. vation to bring the different aspects of the policy together. Belaúnde attempted to shift development priorities to rural areas, but in the process totally neglected the settlements and failed to curb their extremely rapid growth in the 1960 . The present government, by contrast, is attempting to divert migration at the same time that it aids settlements. Likewise, Odria appears to have maintained political control in part by neglecting legalization, presumably at great cost to the settlement residents. The present government is controlling the political life of the settlements at the same time that it is granting land titles.

This difference between the Odría and Velasco periods merits close attention. The informality and paternalism of the policy under Odría involved a political relationship which Powell has called clientelistic. In discussing this type of relationship, Powell has written that the

contract between patron and client ... is a private, unwritten, informal agreement, and highly personalistic in content.

There is no public scrutiny of the terms of such agreements. ... This stands in sharp contrast to the relationship... in modern systems of political transactions. In essence, the patron-client pattern occurs in the realm of private accountability, the modern pattern in the realm of public accountability. ${ }^{115}$

In the clientelist relationship, the lack of public accountability obviously works to the disadvantage of the client, because of

the degree of power asymmetry between superior and subordinate. Superiors in a clientele system are relatively free to behave in an arbitrary and highly personalistic manner

115 John Duncan Powell, "Peasant Society and Clientelist Politics," American Political Science Review 64, no. 2 (June 1970) pp. 429-424.
Squatter Settlements and Policy-177

in dealing with their subordinates. Subordinates in a

clientele system have relatively little recourse in such a situation. ${ }^{116}$

The present government, by contrast, is relying on a system of control which is quite properly called corporative. ${ }^{117}$ It is based on the comprehensive organization of the settlements which has been carried out by ONDEPJOV and SINAMOS. By channeling all aid programs, public and private, through this organizational structure, SINAMOS has attempted to fill the political space in the settlements, drastically reducing the number of alternative courses of political action open to settlement residents. The high degree of power asymmetry described by Powell is still present, but a tendency for superiors to behave in an arbitrary and highly personalistic manner is not. Indeed, one of the most important features of the organizational system set up by SINAMOS is that it is consistent and predictable.

Though these methods for ordering political relationships in the settlements would appear to be remarkably comprehensive and complete, there is no guarantee that they will accomplish the goals which the government seeks to accomplish. Questions about the prospects for SINAMOS's role in the settlements also arise, because the political position of SINAMOS is by no means secure. SINAMOS has important enemies within the government, and some of its programs have stirred strong opposition both in and outside the government. The settlement residents themselves may become dissatisfied with the SINAMOS program in settlements.

However, Dietz reports that as of 1973 the existing arrangement was quite satisfactory from the point of view of the settlement residents. ${ }^{118} \mathrm{He}$ suggests that in the absence of the earlier party competition in settlements, the residents can now concentrate their demands for assistance with local improvements on the appropriate SINAMOS officials, allowing the residents to be more effective in their demand making with regard to local issues and in their efforts to improve their own communities. It is precisely this kind of demand making and self-help that the govern-

116 Ibid., p. 424 .

117 See Julio Cotlex, "The New Mode of Political Domination in Peru," Chapter 2 in this volume.

118 Dietz, "The Office and the Poblador." 
178-David Collier

ment wishes to encourage. Hence, although the political upheavals and the looming presidential succession crisis of 1975 appear to have weakened government performance in most areas of policy, it would appear that the government's program in settlements has made some important strides toward achieving its goals. 